\author{
Santiago M. López García \\ Salamanca University (Spain)
}

\title{
Science and Business
}

\begin{abstract}
There are two kinds of scientists in evolutionary studies that need a space of debate: the specialists in evolutionary studies in business and all other evolutionary scientists in general. The themes of the discussion are the behaviour, growth, reproduction, and organizational structures of the firm.
\end{abstract}

Keywords: Science; Evolution; Firm; Innovation

This section of the Journal of Evolutionary Studies in Business will be a meeting point for two kinds of scientists: specialists in evolutionary studies in business and all other evolutionary scientists in general. In the first category of experts we can find scientists that observe firms, markets, and industries from the perspective of behavioural economics, neuroeconomics, institutional economics, neo-Schumpeterian economics, innovation economics, cultural economics, evolutionary game theory, and complexity economics. On the other hand, there are two different groups of evolutionary scientists. The first group is related to the life sciences: sociobiology, evolutionary psychology, evolutionary neuroscience, population dynamics, ecology, and ethology. The second group includes colleagues from two evolutionary humanities disciplines: anthropology and the philosophy of science.

Corresponding author. E-mail: slopez@usal.es

Received 30 October 2015 - Accepted 11 December 2015

This is an Open Access article distributed under the terms of the Creative Commons Attribution-Non-Commercial-No Derivatives License (http://creativecommons.org/licenses/by-nc-nd/4.0/), which permits non-comercial re-use and distribution, provided the original work is properly cited, and is not altered or transformed in any way. 
The themes of the discussion shall be the behaviour, growth, reproduction, and organizational structures of the firm. As a consequence of this, we must exclude two critical disciplines in evolutionary studies: archaeology and palaeontology. Any speculation about firms before the emergence of capitalism makes very little sense. Even so, certain references to these disciplines shall be nearly inevitable because both are based on the study of the eusociality of humans. Eusociality is a constant that can be found in all our institutions since the first human groups 120,000 years ago (e.g. tribes) and up until the present (e.g. firms).

The structure of this section will be based on interviews focused on discussion about what a firm is from the point of view of each scientific field. This reflexion will be inserted into the context of websites and blogs that are related to the topics chosen each time. Imagine that we are analysing the firm with a neuroscientist, then a useful approach to neuroscience and business analysis could be found on a website such as Medina's Brain Rules (http://brainrules.net/introduction). Our intention is to present opinions directly, without any guidance or comment that could distort the experts' ideas. We will merely introduce a limited number of links to relevant websites.

Why do we want to be so impartial with the experts' answers? The specific objective of this section is to break open the paradigm of the ecological model of competitive interaction between firms that is dominant in business literature related to the evolutionary perspective. We are academics that wish to unlock the backward-looking concept of ecological competitiveness; a notion that is rigid because it is dominated by the emblematic beliefs of economic efficiency and profit maximization. In simplistic business analysis it is common to blend adaptation with maximization. However, these are two different concepts. 
In evolutionary analysis, adaptation always has two sides: reproductive efficiency (species survival) and efficiency regarding the use of the environment (individual survival). This double nature of adaptation is lost in simplistic business analysis.

When we ask life scientists what a firm is for them from their respective evolutionary perspectives, adaptation is always revealed as a double-sided concept. When we introduce this notion of adaptation a Pandora's box is opened. This is our objective in this section: we wish to arouse our fears and insecurities regarding the central concepts of evolutionary approaches. One of these central concepts is adaptation, which is used thoughtlessly by business analysts.

More than eighty years ago, Schumpeter envisioned this kind of challenge. He understood firms as spaces that produce innovation and he related the capacity to innovate with the capacity of firms to reproduce. Moreover, he managed to see this right in the historical moment when these processes were experiencing considerable growth.

From a Schumpeterian perspective, innovation is the direct consequence of the phenomenon of firms' reproduction, which is spurred by the forces of competition. Competition is the driving force of the process that he called 'creative destruction', but, as Edith Penrose stressed, we are not talking about perfect competition, but innovative competition:

The society characterized by a widespread 'spirit of enterprise' and a highly developed technology, the threat of competition from new products, new techniques, new channels of distribution, new ways of influencing consumer demand, is in many ways a more important influence on the conduct of existing producers than any other kind of competition. (Penrose $1995,113)$

She identified the epistemological problem: what is the relationship between the type of competition and the reproduction of firms? For years, industrial economics has offered an 
extremely simple understanding of firm reproduction, considering it merely as the process of births, mergers, acquisitions, and collapse of firms. Perhaps in a world of perfect competition this was a valid answer, but in a society of innovative competition it is not.

The common understanding of the ecology of firms has little to do with the idea of species competing in an environment. A scientific ecology of firms should be closer to the type of competition that occurs, for example, in the colonies of a coral reef. If we adopt this perspective then we can answer the question about what firm reproduction is.

Reproduction is based on the continuous interchange of managers, professionals, and workers. They (managers and so on) are like the polyps in a coral colony. Without an intense process of losses and gains (understood as exchanges of people that leave the firm and others that join), firms lose their innovation capacity and this is substituted by countless path dependencies. We must not forget that the phenotype (innovation) is a reflection of the genotype (the knowledge of the managers, professionals, and workers that are combined within the walls of a firm). This analogy (firms as coral colonies) helps us understand, firstly, the resource-based view of the firm (a pool of resources), and, secondly, why competitiveness is the essential conduct of all firms. Usually we associate competitiveness with the microeconomic foundation that resides only in the owner of the firm and its investors. However, competitiveness is also and essentially an attribute of managers, professionals, and workers. They fend off other employees (polyps) that are working in others firms (colonies) in the struggle for a strategic place in the market (reef). Penrose came very close to this vision of the firm when trying to unravel the causes of company growth. At the end of the 1950s and the beginning of the 1960s Penrose, A. Chandler (1962), and R. L. Marris (1961) defined the 
phenomenon as 'managerial capitalism' or the 'managerial firm'. Within this perspective, Penrose states the following:

I also assumed that managers qua managers were primarily interested in the profitable expansion of the activities of their firm. Profits were treated as a necessary condition of expansion -or growth - and growth, therefore, was a chief reason for the interest of managers in profits. Moreover, the more profits that could be retained in the firm the better, for retained earnings are a relatively cheap source of finance; management had no desire to pay out to shareholders more dividends than were necessary to keep the capital market happy. (...) I argued that managerial resources with experience within the firm are necessary for efficient absorption of managers from outside the firm. Thus the availability of 'inherited managers' with such experience limits the amount of expansion that can be planned and undertaken in any period of time. Such managers, by definition, cannot be acquired from the market but are a necessary input in expansion. (Penrose 1995, XII).

She was also close to this vision when she introduced her concept of 'management team'. According to Penrose a management team is a team of employees able to provide services and experiences that are uniquely valuable for the operations of the particular group with which they are associated (Penrose 1995, 46). These services and experiences are crucial for the firm and allow the team gain more relevance. Sometimes the team cannot supply the service, and then the group details a 'job description' with the objective of the firm hiring people to fill the various positions that the team needs. This process is the mechanism of reproduction of the firm and the key to its growth. The new reconfiguration of knowledge creates innovations and the firm starts a new process of adaptation to a changing environment. Sometimes, if the 'team' considers that the firm does not make enough effort, this process could mean the end of the company. The 'team' can establish a new firm or enter a firm that forms part of the 
competition. All of these processes are forms of reproduction, like the polyps involved in the reproduction of a coral reef. These characteristics of the management team were revealed by J. M. Valdaliso and S. López (2006) under the concept of grupos diseñadores, which we can translate as 'planning groups'.

These are the types of controversial issues we hope shall arise in this section. With the two groups (experts in life sciences and specialists in evolutionary humanities), we want to stimulate a discussion about the evolutionary bases of business, which will reveal firms as human institutions that adapt to and survive in a changing environment.

A final issue: why is history (economic history and business history) absent from this approach to evolutionary economics? Why have we not mentioned the history that exists between the evolutionary humanities? The historical account, like the historical narrative, is based on a continuum of cause and effect relationships. We could call this is 'evolution', but by recounting events one after another we are not necessarily tracing a natural evolutionary history of our subject.

\section{References}

Chandler, Alfred D. Jr.. 1962. Strategy and Structure: Chapters in the History of the American Industrial Enterprise. Cambridge: MA, MIT Press.

Marris, R. L. 1961. "Review of the Theory of the Growth of the Firm." Economic Journal 71:144-148. Penrose, Edith. 1995. The Theory of the Growth of the Firm. Oxford: Oxford University Press.

Valdaliso, Jesús M. and Santiago M. López. 2006. Historia económica de la empresa. Barcelona: Crítica.

This is an Open Access article distributed under the terms of the Creative Commons Attribution-Non-Commercial-No Derivatives License (http://creativecommons.org/licenses/by-nc-nd/4.0/), which permits non-comercial re-use and distribution, provided the original work is properly cited, and is not altered or transformed in any way. 